\title{
Rare Diseases in Mediaeval Europe
}

\section{Dooms $M^{*}$}

Center for Clinical Pharmacology, Historical Archive University Hospitals Leuven, Belgium

*Corresponding author: Dooms M, Center for Clinical Pharmacology, Historical Archive University Hospitals Leuven, KULeuven, HistArUz, Belgium

\begin{abstract}
Monastic rules made an end to infanticide and child neglect in the Middle-Ages by caring for children with (rare) disorders: Disabled and impaired citizens became part of daily life. Historic, paleo-pathological, iconographic and genetic research revealed several cases of acromegaly, achondroplasia, alpha-1-antitrypsin deficiency, cystic fibrosis, Down syndrome, Dupuytren's contraction, goiter, Marfan syndrome, Paget's disease and phenylketonuria. These observations want to illustrate that diseases with a low prevalence are not recent observations but already existed for many centuries.
\end{abstract}

\section{Keywords}

Paleopathology, Orphan drugs, Child oblation, Genetic epidemiology, Middle-ages

\section{Background}

In the early Middle-Ages medicine was based upon surviving texts, mainly Greek (mostly translated in Latin) but also Roman documents and was mainly practiced in monasteries. Sick people placed their hopes in God as in their minds sin, destiny and astral influences played an important role in the origin of a disease. Monks and nuns (Hildegard von Bingen 1098-1179) could read the medical text books written or translated in the Latin language. They practiced in an infirmarium (sickbay for intra muros patients with an infirmarius) as well as an hospitium or xenodochium (sickbay for extra muros patients with an hospitalarius) which had a botanical garden. Many abbeys had a minutorium or phlebotomarium where a male minutus or female minutrix performed bloodlettings with a minutor or phlebotomator following the rules of the Liber Floridus. The Carolingian-era monastery of Saint Gallen (719) served as an ideal "prototype" for these mediaeval monasteries with the mod- el of an infirmarium/hospitium that could be a church. Besides medical treatment, these monasteries were hostels for pilgrims and travelers, for the elderly and homeless people. Benedict's Rule admonished monks to care for the sick within the confines of the monastery (Mat 10:8). Later on the church started to oppose these medical practices as they feared it would distract the clergy, living celibate and freed from all personal possessions, from their spiritual activities. Taking care (caritas) of female patients and all the money involved in these activities was also not looked on favorably. In 1215 the Fourth Council of the Lateran (http://www. papalencyclicals.net/councils/ecum12-2.htm\#18) prohibited all medical activities in monasteries in the papal bull "Vineam Domini Sabaoth" and in the $50^{\text {th }}$ constitution of this same bull, prohibition of marriage became restricted to the fourth degree (consanguinity) which subsequently had his impact on the incidence [1] and mortality [2] of rare disorders.

The philosophy between the practice of medicine in Mediaeval times compared to contemporary medicine is in marked contrast. Anorectics in the Middle Ages for example, wanted to achieve spiritual perfection and not physical perfection as it is today [3]. Religious women saw in their own female bodies a symbol of the humanity of God ("imitatio Christi"). They gloried in the pain, the blood and the somatic distortions which they believed made their bodies parallel to the man on the cross. Women's bodies, in the acts of giving birth and lactation, were therefore analogous both to ordinary food and to the body of Christ. When Jesus died on the cross he gave birth to salvation. In a fierce imitation of the sufferings of Jesus on the cross their rituals included self-flagellation, self-starvation, and acute illness and

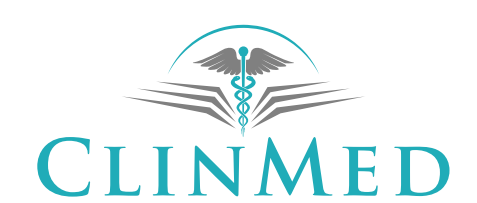

INTERNATIONAL LIBRARY
Citation: Dooms M (2020) Rare Diseases in Mediaeval Europe. Int J Rare Dis Disord 3:016. doi. org/10.23937/2643-4571/1710016

Accepted: March 26, 2020; Published: March 28, 2020

Copyright: (C) 2020 Dooms M. This is an open-access article distributed under the terms of the Creative Commons Attribution License, which permits unrestricted use, distribution, and reproduction in any medium, provided the original author and source are credited. 
by doing so women became the macerated body of the Savior [4]. St Francis of Assisi was reported to carry stigmata, bodily wounds, scars and pain in locations corresponding to the crucifixion wounds of Jesus Christ. But living physically impaired people had received their impairment, wounds or mutilation involuntarily [5].

The disabled, impaired, chronically ill were spontaneously part of the daily life in a society that was accepted as being multifaceted, diversified, disparate. Impairment meant a compromised physical or biological function while disability a state of social and physical exclusion. It was more than tolerance; it was real life, with which one compromised as best one could, without wishing to change it by various techniques and various treatments, and without wishing to exclude it either. Patients with rare disorders demonstrated what could happen to the human body. In other words they confirmed the normality of the others. They constituted a difference to be loved, helped, aided, furthered. They were a kind of trials on the one hand, as opportunities to exercise our greatest virtue, charity, on the other and thirdly as the sign of his presence [6].

While there is evidence for care in child burials, paleopathological observations of child skeletons could suggest that parenteral detachment was greatest when a child was frail and likely to die and that caring for the strongest children was a form of evolutionary adaptation. A newborn with serious malformations (phantasmata) would probably not have survived after birth and the early death of children with cranial deformities may suggest their disposal or that they died from an associated pathology [7]. The Istituto degli Innocenti in Firenze (1419), designed by Filippo Brunelleschi (1377-1446), was the first secular institution to adopt children (1445) through a pila (grated window). The babies were wet nursed and weaned, boys were teached reading and writing, girls household tasks.

In the early Middle Ages child oblation was common practice by the upper classes and was mainly driven by economic gain, ridding themselves of superfluous offspring and the expectation of a divine reward ("quid pro quo") to ensure afterlife in heaven. Women carried am-

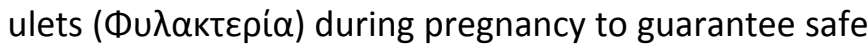
delivery. As plenty of these healthy children found their way to the monastery, it was the opposite of abandonment. Moreover, there was nothing especially callous in selecting a child with a (rare) disorder for oblation ("Notker Balbulus"/the Stammerer or "Hermannus Contractus"/the Cripple, etc) as monastic life would give him/her scope to develop his/her talents in directions not requiring physical prowess [8,9]. The composer and scientist Hermannus Contractus (1013-1054) suffered from amyotrophic lateral sclerosis or spinal muscular atrophy and was placed in a Benedictine monastery in Reichenau.

\section{Historic, Paleo-pathological, Iconographic and Ge- netic evidence}

Disabled/impaired people were found among all parts of society. Monarchs across Europe were noted as having those with disabilities/impairments in their courts where they filled roles such as that of the King's Fool or court jester. Despite some ambiguity, this rank gave the disabled/impaired person a level of prestige and standing in society. A few notable cases of rare disorders such as glass delusion occurred during the Late Middle Ages. A notable case was King Charles VI of France (1368-1422). This mental disorder ("mente capti") involved a person believing that they were made of glass and were fragile and able to break or shatter upon impact. King Henry the VI of England (1453-1471) slipped into long-lasting cationic states several times in his life. Pepin the Hunchback (769-811), oldest son Charlemagne, was disinherited, tonsured and died in anonymity in the monastery of Prum [10] possibly because of his disability. Egill Skallagrimsson, main character in Egils Saga (Snorri Sturluson, Iceland: 1179-1241), suffered most probably from Paget's disease. Several paleopathological reports have been published about rare disorders in the Middle Ages such as meningioma's [11], Down syndrome [12], acromegaly [13], achondroplasia [14], multiple myeloma [15], Marfan syndrome ([16], poster 11) amylogenesis imperfecta [16] and metabolic bone diseases [17]. Iconographic research of Mediaeval art reveals the representation of several rare disorders such as dwarfism by Andrea Mantegna (1431-1506) in his "The Bridal Chamber", a giant trilobal goiter in 1474 [18], Paget's disease by Quinten Matsys (1466-1530) [19], myasthenia gravis by Hans Holbein (1497-1543) [20], myotonic dystrophy by Pieter Bruegel the Elder (1525-1569) [21] and Behçet's disease by an anonymous medieval artist [20]. Dupuytren's contraction (palmar fibromatosis) was called Viking Disease as it was wrongly thought to be spread throughout Northern Europe in the Middle Ages by the Vikings [22,23], old Norse-speaking peoples with strong links with continental Europe. Alpha-1 Antitrypsin Deficiency protected Vikings from massive parasite infections after having eaten contaminated food but predisposed people later to emphysema and other lung conditions [24]. Other rare genetic disorders could also be traced by using techniques of genetic epidemiology like phenylketonuria in Ireland [25] and cystic fibrosis in the northern part of Europe [26]. Stories about werewolves and vampires may have been inspired by patients suffering from congenital erythropoietic porphyria searching for blood (heme treatment) during the night (photosensitivity) [27].

The Deutsches Archäeologisches Institut Berlin produced a Digital Atlas of Rare Diseases and organized the first workshop on Ancient Rare Diseases in Berlin [16]. Speakers from the Croatian Academy of Sciences \& Arts 
and the Universities of Szeged \& Insubria together with poster presentations from Transylvania Bioarcheology, Institute of Archaeology in Kiev and OsteoArc confirmed the existence of several cases of rare diseases in Mediaeval times.

The British Museum in London (Room 63) displays several objects illustrating rare diseases in ancient times such as a cartonnage mummy case and skeleton of a young child who suffered from osteogenesis imperfecta (Egypt, 945-716 BC) and an early example of metastatic rare carcinoma.

\section{Pioneers of modern medicine}

Al-Zahrawi (936-1013) or Abulcasis in Latin, was an Arab-Muslim physician-surgeon in Al-Andalus (now the major part of today's Spain) and is considered as the "father of surgery". He was the first physician to identify the genetic nature ("destiny") of hemophilia [28] and performed the first surgery on hydrocephaly which he described as an evacuation of superficial fluid. In 1140 the monks in the Tre Fontane abbey suffered from a rare disease (possibly malaria) caused by an insect (Anopheles mosquito?) living in the standing waters of the Aquae Salviae. Paracelsus (1493-1541) may be considered as the founder of toxicology/pharmacology by stating that all substances are poisons and that only the right dose substantiates a poison and a remedy. In (rare) hematologic diseases ("poor blood") he introduced the use of "iron" in a correct dose. Pope John XXI (1215-1277) was an important person in pharmacotherapy due to his knowledge of herbal remedies. He also wrote "De Oculis", a book on (rare) eye diseases in the $13^{\text {th }}$ century [29]. Haematochromatosis, illustrated by Giovanni Battista Caracciolo (1578-1635), was treated by putting blood sucking leeches on the skin lowering the excess iron content. Other important doctors medicinae were Hunayn ibn Ishaq (809-873), Ibn Sina (alias Avicenna: 980-1037) with the "Canon of Medicine" and Al-Razi (alias Rhazes: 865-925) with his "Liber Continens". Hildegard von Bingen (1098-1179) contributed with "De Mulierum Passionibus" (On the Diseases of Women) and "The Trotula" (Salerno, 1187).

\section{Medical practices in mediaeval monasteries}

The Medieval church was concerned with the moral implications ("Summae Confessorum") of the medical profession. Physicians' expertise had to be evaluated according to the accepted standards (today called Guidelines) and experimenting on patients limited (today called Good Clinical Practice). Physicians in doubt about the effects of a particular medicine (today called Off-label Use) should leave the patient in God's hands rather than expose him/her to the danger of an untried medicine [30].

Two examples of monasteries where I did some research in their old libraries:

The Park abbey was founded in 1129 in a park, formerly a hunting ground, near Leuven, Belgium by the Premonstatensians. This is 300 years before the founding of the Faculty of Medicine of the Catholic University of Leuven, one of the first universities in Europe. The historic library of this abbey (Figure 1) contains more than 5000 books edited as early as 1470 to 1830 ("Monasterium sine armario quasi castrum sine armamentario"/a convent without a library is like a castle without arms). The librarian ("armarius") was responsible for the books that were mainly used during the "Lectio Divina", the reading of religious texts during meals or in private sessions ("In gratiam omnium studiosorum"/in favour of all those who study). The big garden around

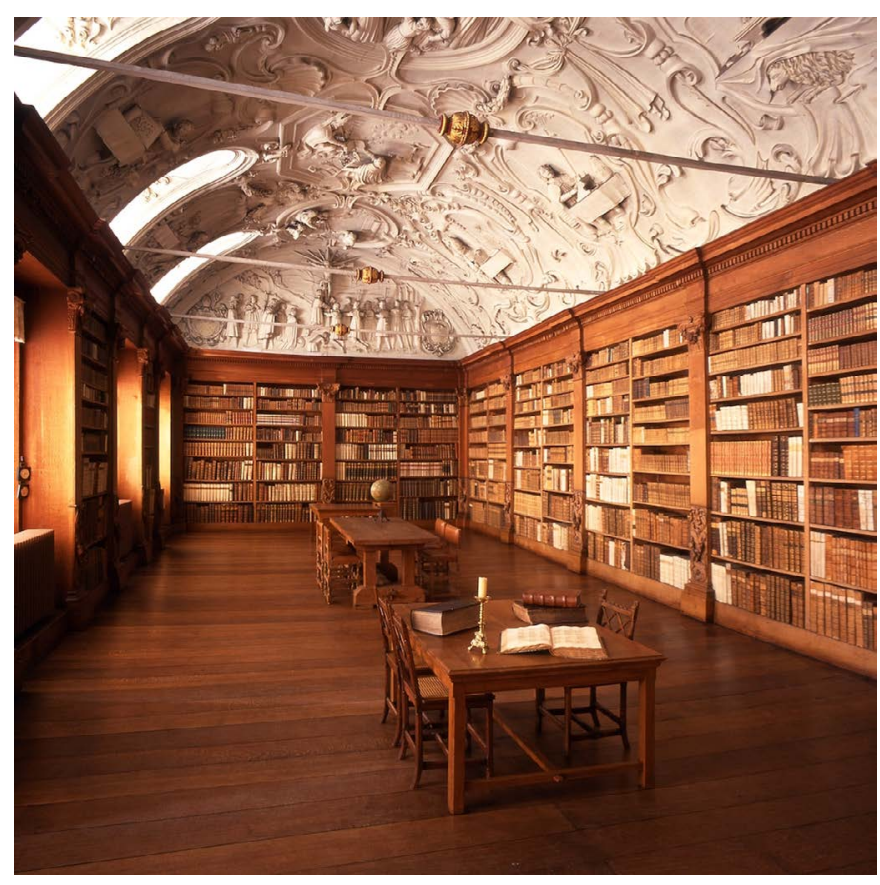

Figure 1: Historical library of the Park Abbey in Leuven. 
the abbey had multiple trees, plants and herbs ("Hortus abbatia"/Abbey garden, "Pomarium"/Orchard) used to make pharmaceutical products (decoctum, hostia, infusio, pilula, potio, pulvis, syrupus, tinctura) according to the monographs of the local pharmacopoeia. The library still holds several historical books on this subject [31-34], and also on surgery [35], medicine [36-38] and general medical practice [39]. It is also interesting to mention the books on embryology $[40,41]$ and the "Dissertatio Theologica de baptizandis abortivis"/Theological dissertation on the baptism of abortions [42]. The historical libraries of several other abbeys in and around Leuven have been destroyed.

The Averbode abbey was founded in 1134 in a duchy, actually named Flemish Brabant, Belgium (Leuven is the capital), also by the Premonstratensians. The abbey was originally small but grew over the centuries to include an hospitium and an infirmarium. Several times the abbey was heavily damaged but most parts of the library and the archive were saved from destruction. The library still holds several books on embryology [40], internal medicine [43-47] and medical herbs [48,49]. Unwanted children and babies with rare disorders were left at the door of the church [50]. The clergy baptized them ("sub conditione") and took care of their upbringing (Figure 2). This may be considered as the decline of infanticide or neglect and the rise of the orphanages (орфаvóтроти) and the early beginnings of solidarity. Ospedale degli Innocenti in Florence may be considered

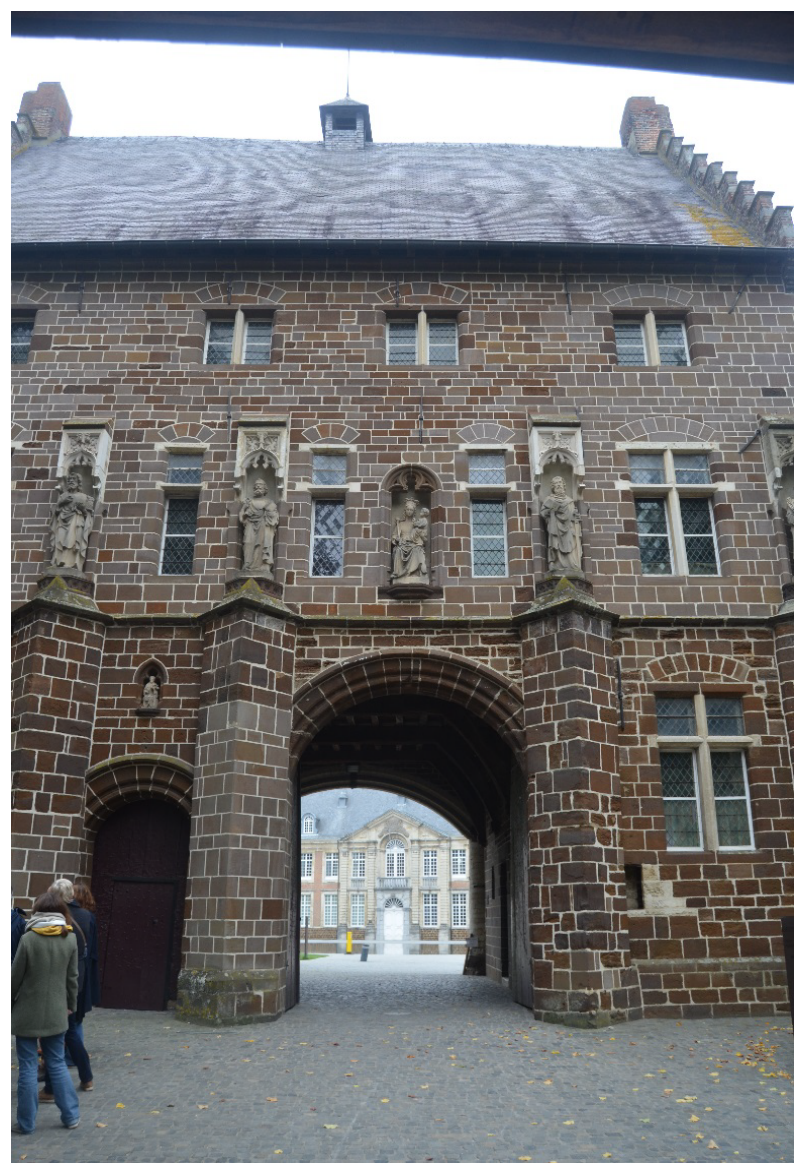

Figure 2: Entrance door of the Averbode Abbey. as the first children's orphanage build outside a monastery.

The library of the San Marco convent (1441) in Firenze also has a whole section ("ex parte accidentis") with medical manuscripts assembled by the Medici and the Laurentian library (1525 by Michelangelo) in Firenze, the first library outside a convent, assembled more than 11000 manuscripts belonging to the private collection of de Medici family.

\section{Discussion}

There is no reason to believe that in Mediaeval Europe there were no diseases with a low prevalence. Iconographic, paleo-pathological and genetic evidence is overwhelming in areas where cremation was not common practice. Illustrations and narratives of patients with rare disorders are indeed artistic portrait paintings and descriptions of these individuals were made by non-medically trained artists [51] but convincing enough for the existence of such a disease. For example the available evidence of the so-called albino's Timur, Zal and Edward the Confessor is insufficient for such a diagnosis [52].

Some authors [5] make a conceptual distinction between physical impairment as a "real", physiological condition, and physical "disability" as a socially constructed or cultural condition. Over the ages the prevalence/incidence of (rare) disorders changed dramatically due to several factors such as preventive measures and better hygiene sometimes even close to extinction (poliomyelitis). Moreover better diagnostic tools identified more precise (rare) indications for a better advanced personalized treatment. But there always have been and always will be diseases with a low prevalence/ incidence.

\section{Conclusion}

Through the ages diseases with a low prevalence have always occurred but physicians did not have the knowledge to prevent nor diagnose, the surgeons not the tools to operate and the pharmacists not the medication to treat patients with common diseases, let alone rare disorders [53]. Moreover during the Middle Ages these patients were accepted as part of everyday life with little desire to change their situation by various techniques or treatments and without wishing to exclude it either. Care (caritas) will slightly change into

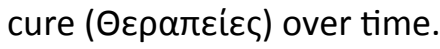

\section{Funding}

This research did not receive any specific grant from funding agencies in the public, commercial or not-forprofit sectors.

\section{References}

1. Hanan Hamamy (2012) Consanguineous marriages. J Community Genet 3: 185-192. 
2. Chisholm JS, Bittles AH (2015) Consanguinity and the developmental origins of health and disease. J Evol Med 3: 1-4.

3. Vedul-Kielsas E, Gotestam KG (2004) Eating disorders in a historical perspective. Tidsskr Nor Laegeforen 124: 23692371.

4. Bynum CW (1987) Holy feast and holy fast. The religious significance of food to medieval women. University of California Press, Berkley, Los Angeles, London.

5. Metzler I (2006) Disability in Medieval Europe. Routledge, London \& New York.

6. Stiker HJ (2007) A history of disability. The University of Michigan Press, Ann Arbor, 65-89.

7. Lewis $M(2016)$ Childcare in the past: The contribution of paleopathology. In: Powell L, Southwell-Wright W, Gowland R, Care in the past. Oxbow, University of Reading.

8. De Jong M (1996) In Samuel's image: Child oblation in the early Medieval West. Köln: EJ Brill, Leiden, New York.

9. Ferngren GB (2014) Medicine \& Religion. A historical introducton. John Hopkins University Press, Baltimore, 93-118.

10. Boelaert JR (2017) Lichaamskwalen en hun verzorging. Geschiedenis van de Geneeskunde en Gezondheidszorg. Garant, Cahier 6.

11. Brothwell M, Brothwell D (2016) Evidence for ancient meningiomas and a probable case from Medieval Tarbat Scotland. Int J Paleopathol 13: 65-69.

12. Rivollat M, Castex D, Hauret L, Tillier A (2014) Ancient down syndrome: An osteological case from Saint-Jeandes-Vignes Northeastern France, from the 5-6th century. Int J Paleopathol 7: 8-14.

13. Hosovski E (1991) A case of acromegaly in the Middle Ages. Anthropol Anz 49: 273-279.

14. Sables A (2010) Rare example of an early medieval dwarf infant from Brownslade, Wales. Int J Osteoarchaeol 20: 4753.

15. Riccomi G, Fornaciari G, Giuffra V (2019) Multiple myeloma in Paleopathology: A critical review. Int L Paleopathol 24: 201-212.

16. WARD (2019).

17. Brickley MB, Ives R (2008) The study of metabolic bone disease in bioarcheology. In the bioarcheology of metabolic bone disease. Academic Press, 7-20.

18. Sean LM, Barale M (2015) Man with enormous trilobal goiter. J Endocrin Invest 38: 575.

19. Laskowska M, Krzeslak A, Form E, Jozwiak P, Brys M (2012) Genetic diseases and other unusual disorders presented in art paintings. Folia Medica Lodziensia 39: 5-19.

20. Dequeker J (2006) De Kunstenaar en de Dokter. Leuven, Davidsfonds, 45.

21. Smith PE (1999) Neurology in the National gallery. J R Soc Med 92: 649-652.

22. Flatt $A E$ (2001) The vikings and baron dupuytren's disease. Proc Bayl Univ Med Cent 14: 378-384.

23. McFarlane RM (2002) On the origin and spread of Dupuytren's disease. J Hand Surg AM 27: 385-390.

24. Quinn PM, Dunne DW, Moore SC, Pleass RJ (2016) IgE-tailpiece associates with alpha-1-antitrypsin (A1AT) to protect IgE from proteolysis without compromising its ability to interact with FcRI. Sci Rep 6: 20509.
25. Zschocke J, Mallory JP, Eiken JG, Nevin NC (1997) Phenylketonuria and the peoples of Northern Ireland. Hum Genet 100: 189-194.

26. Devoto M (1991) Origin and diffusion of the major cystic fibrosis mutation in Europe. The European Working Group on CF Genetics (EWGCFG). Adv Exp Med Biol 290: 63-71.

27. Maas RP, Voets PJ (2014) The vampire in medical perspective: Myth or malady. QJM 107: 945-946.

28. Ingram GI (1976) The history of haemophilia. J Clin Pathol 29: 469-479.

29. Daly WJ, Yee RD (2001) The eye book of master peter of Spain: A glimpse of diagnosis and treatment of eye diseases in the middle ages. Doc Ophthamlol 103: 119-153.

30. Quantin PM (1959) À propos des premières Summae Confessorum: Théologie et droit canonique. Recherche de théologie ancienne et médiévale 26: 264-306.

31. De Villa Nova Arnoldus (1554) De concervanda bona: De electione meliorum simplicium ac specierum medicinalium. Egenolphi, Frankfurt.

32. (1734) Ordonnanti der Heeren Wethouderen op het taxaet der drogen ende medicamenten raeckende de pharmacie van de Apothekarissen der Stadt Brussel. Brussel.

33. Orfil, Mathieu-Joseph-Bonaventure (1818) Traité des poisons tirés des règnes minéral, végétal et animal. Toxicologie générale. Crochard, Paris.

34. Sassenus, Andreas Dominicus (1704) Pharmacopoeiam Bruxellensem. Brussel.

35. Guillemeau Jacques (1649) Les oeuvres de chirurgies. Rouen, Jean Viret.

36. Baglivi Giorgio (1737) Opera omnia medico-practica, et anatomica.

37. Castelini Bartholomeo (1746) Lexicon medicum graeco-latinum. De Tournes, Geneva.

38. Swieten Gerardus Van (1740) Commentaria in Hermannia Boerhaave Aphorismos de cognoscendis et curandis morbis.

39. Cheyne George (1727) Règles sur la santé et sur les moyens de prolonger la vie. Jean Léonard, Bruxelles.

40. Cangiamila Franciscus Emmanuel (1775) Sacra Embryologica. Walwein.

41. Dinouart Joseph Antoine Toussaint (1774) Abrégé de l'embryologie sacrée: Traité des devoirs des prètres, des médecins, des chirurgiens et des sage- femmes envers les enfants qui sont dans le sein de leurs mères. Nyon, Paris.

42. (1776) Dissertatio theologica de baptizandis abortivis. Leuven.

43. Cornelius Celsus (1497) Medicinae libri VIII. Philippus Pinzi, Venetiis.

44. Bertrucius (1537) Compendium sive collectorium artis medicae tam practicae quam speculativae. Melchior Novesianus, Coloniae.

45. Cornelius a Baersdorp Godenis (1538) Methodus universae artis medicae formulis expressa. Hubertus Crocus, Bruge.

46. Galenus (1539) Methodus sex librorum in differentibus et causis morborum et symptomatum. Christianus Wechelus, Parisis.

47. Ludovicus Antonius (1540) De re medica opera. Olyssipontis, Ludovicus Rotoricius. 
48. Jean Molanus, Hendrik Van Cuyck, Joannes Walters Viringus, Joannes Masius, Philippus Zangrius (1595) Medicorum ecclesiasticum diarium. Lovanii.

49. Johannes Veldenez (1485) Herbarium.

50. Gerits TJ, Praem O (1970) Vondelingen aan de abdijpoort te Averbode. Meer Schoonheid 17: 104-106.
51. Mitchell PD (2011) Retrospective diagnosis and the use of historical texts for investigating disease in the past. Int $\mathrm{J}$ Paleopathol 1: 81-88.

52. Froggatt $P$ (1962) The albinism of timur, zal and edward the confessor. Med Hist 6: 328-342.

53. Dooms MM (2015) Rare diseases and orphan drugs: 500 years ago. Orphanet J Rare Dis 10: 161. 